\title{
The Interaction between Learners and Learner-Facilitator in an Online Learning Environment
}

\author{
Ronit Hesrcu-Kluska \\ Department of Natural Science and Environmental Education, ORANIM Academic College of Education, Tivon, Israel \\ Email: ronit_k@oranim.ac.il
}

How to cite this paper: Hesrcu-Kluska, R. (2019). The Interaction between Learners and Learner-Facilitator in an Online Learning Environment. Creative Education, 10, 1713-1730.

https://doi.org/10.4236/ce.2019.107122

Received: January 1, 2019

Accepted: July 28, 2019

Published: July 31, 2019

Copyright $\odot 2019$ by author(s) and Scientific Research Publishing Inc. This work is licensed under the Creative Commons Attribution International License (CC BY 4.0).

http://creativecommons.org/licenses/by/4.0/

\section{cc) (i) Open Access}

\begin{abstract}
We live in an online computerized world; the online environment reaches every part of the modern life and therefore studying and learning as well. As the concept of learning in an online environment increasing, some questions are raising: Does online learning change the learner's interaction? Does online learning change the learner- facilitator interaction? This Autoethnography study is trying to shed some light on these two types of relations, from an individual learner point of view. The study raises the need to pay attention to the interactions between learners and the learners-teacher/facilitator as an online course being planned and pay attention to these interactions as the online course develops, especially at learning in a collaborative learning group. That type of learning requires an interaction between the students, though online learning seems to ignore the need for learners' collaboration. Moreover, the interaction between learners and the facilitator in an online course often attend to a more technical point of view. This Autoethnography study shows that although we live in a computerized world, learning in an online environment is not self-evident, and we need to thoroughly consider how online courses should be built and whether they can fully replace traditional courses. In addition, an indirect finding emerged in this study, which is the complexity of the online student-facilitator interaction from the educational-pedagogical point of view. Since this study is autoethnographic it reflects an individual learner's perspective, allowing to examine these interactions through particular lens. Therefore, each participator may reach different findings regarding his or her personal experience as a learner in an online learning environment.
\end{abstract}

\section{Keywords}

Collaborative Learning, Online Learning, Distance Learning, Autoethnography 


\section{Introduction}

Collaborative learning in an online environment is a learning setting that has entered the field of teaching as the Internet and its usage developed.

The Internet has greatly expanded the use of distance learning methods and has enabled either a variety of pedagogical method, or a new use and meaning to well-known methods.

Though the collaborative learning has risen as a pedagogical method long before the establishment of the internet, it seems that the attitude, "the roles" did not change. The learners must behave as a group and maintain the principles of collaborative learning in the traditional method, and only thus will they reach interaction and cooperation between participants (Royer, 1997; Ragoonaden, 2000).

The method of distance learning in the online environment has many advantages, most of which lie in the fact that it enables learning even when there is no physical ability to reach an academic institution. However, there are a number of drawbacks associated with this method, for example, the problems arising from asynchronous learning, which can reduce the motivation of learners and even cause contempt for learning the method (Konak, Kulturel-Konak, \& Cheung, 2018; Ragoonaden, 2000; Jaggars \& Xu, 2016; Petersen, 2016).

The difficulty of distance learning is also due to the loss of eye contact and the visual innuendos that are common in the traditional classroom (Harasim, 1987; Gunawardena, 1995; Somaratne, 2015). The use of the lecturer's voice or the students' in the traditional classroom also contains information that is lost in an online learning environment (Harasim, 1987). In order to overcome some of these difficulties it is important to create a sense of community and interaction between learners (Gunawardena, 1995; Somaratne, 2015).

The concept of Social Presence as a situation in which two or more people feel socially close to each other even though both are physically distant from one another. Creating a sense of closeness in the online medium is needed to compensate for the lack of eye contact and physical reality.

Distance learning becomes more complex when learners are exposed to new cultures, new learning environments, and interacting with a wider and more diverse range of learners.

This study will examine the impact of the annual course, the advanced teaching environment and the multi-participant and multicultural environment on the learner in the course. The impact of multicultural learning on students will be examined, the students' feelings in a multi-participant course discussed, as well as the group's ability to function as an active and cooperative learning group over time. We will examine whether a lengthy course, of one year, can change the learner's world view throughout the course and influence it. And whether the changes in perception of the teacher-in-training during the course have an impact on the teacher's attitudes in the future and do these changes in perception have the ability to improve their pedagogical performance?

The significance of this exploration stems from the importance of the teach- 
er-in-training's perception as it applies to their future function as teachers. Does the ability exist to expose the teacher-in-training, at the stage of forming their identity as future teachers, to different cultures, to advanced teaching methods, and thus to influence their establishment as educators?

\subsection{What Is an E-Learning Environment?}

Communication between computers began in the 1960s with the beginning of the ARPANET network, which is a name that consists of the acronym Advanced Research Projects Agency Network (Harasim, Hiltz, Telese, \& Turoff, 1995; Harasim, 1987; Harasim, 2018). People who worked at terminals were connected to a central computer and sent each other short messages, at first, and later e-mail messages. At first, users were in physical proximity to the main computer and later ARPANET became a network connecting computers from different countries. At the end of the 1970s, institutions of higher education joined the emerging communications network, which led to an increase in the network's uses and the significance of the connection between researchers from institutions around the world. During the 1980s the network changed its name to The Internet (Hunter, 1992; Harasim et al., 1995; Harasim, Calvert, \& Groeneboer, 1996).

In the late 1960s, the first attempt was made to use the computer as a teaching tool by Stanford University. Students with low socioeconomic backgrounds studied computer-assisted mathematics (CAI-Computer Assisted Instruction) (Hunter 1992). During the 1970s, the use of e-mail enabled university researchers to share information and conduct joint research, and later, students in university courses could exchange information (Harasim et al., 1995). The use of computers was instrumental in teaching, and it was reported that the time taken to learn was reduced as a result of computer use in mathematics studies (Kulik, Kulik, \& Cohen, 1980). With the development of the World Wide Web in the early 1990s (Schatz \& Hardin, 1994; Crossman, 1996), the learning environments underwent rapid evolution into Internet and WWW systems. These systems have revolutionized the use of computer communication as a means of transferring and storing information because the creation and distribution of information has become simple and easy to use, and in effect, an international standard (Goldberg et al., 1996; Campbell, Hurley, Jones, \& Stephens, 1995; Crossman, 1996).

Since the 1990s, and especially in recent years, all academic institutions offer courses via computer communications and the Internet. Vigotzky (1978) argued that learning is more meaningful when students learn in supportive learning environments, and when they receive adequate support with appropriate tools. There is an upper and lower limit of abilities. The lower limit signifies existing abilities while the higher signifies abilities that can be realized through support and appropriate tools. A properly structured online learning environment will enable the student to reach the upper limit while receiving support from the teacher (Relan \& Gillani, 1996; Vygotsky \& Cole, 2018). Learning is meaningful 
only when there is a connection between prior knowledge and acquired knowledge. Learning environments should, therefore, contain tools for organizing learning, searching and locating, creating new content and presenting it (Gillani \& Relan, 1996; Othman, Ayop, \& Karim, 2015; Resta, Searson, Patru, Knezek, \& Voogt, 2011).

The Web's linked environment makes it easier to connect students to the learning community, to distance learning, more so than in the past, and to reach anywhere in the world (Goldberg et al., 1996). The Web environment is easy to use and is becoming increasingly popular (Goldberg et al., 1996; Shneiderman, Borkowski, Alavi, \& Norman, 1998).

\subsection{Difficulties with Online Learning Processes}

Many students need physical feedback, but physical feedback does not exist in online learning (Hiltz, 1992; Wigand, 2018). The physical connection with other learners in the traditional classroom often leads to competition among learners which also does not exist in the online environment. The learner finds himself isolated and the immediate feedback he is used to receiving from a teacher does not exist in learning based partly on asynchronous communication. The use of technology is also an additional difficulty for the learner as well as for the teacher. Students must have high motivation and personal responsibility, develop high personal initiative, have reasonable personal assessment, not require constant reinforcement, and be willing to communicate with the other learners in order to facilitate the group learning process (Harasim et al., 1995; Beigi \& Liu, 2018; Beigi, Shu, Zhang, \& Liu, 2018). Access to technology is one of the most difficult problems to face in online learning environments (Harasim et al., 1995; Palloff \& Pratt, 2002; Poë, 2015). The apparent ease with which technology is used by some is not shared by all (Hiltz, 1992; Islam, Beer, \& Slack, 2015).

\subsection{Collaborative Learning}

Collaborative learning is the interaction between participants in a coordinated effort to solve a problem (Dillenbourg, Baker, Blaye, \& O'malley, 1995; Dillenbourg \& Schneider 1995; Shonfeld \& Gibson, 2018). Collaborative learning is expressed in the implementation of educational tasks that include exchanging information and sharing among a number of learners. Online learning enables us to overcome logistical obstacles that include the need for face-to-face encounters which facilitates and supports collaborative learning. Cooperative learning changes the relationship between the learners and between the learner and the teacher. The teacher goes from being an authority figure to an adviser and source of knowledge (Harasim et al., 1995; Harasim et al., 1996; Magen-Nagar \& Shonfeld, 2018; Duchastel \& Turcotte, 1996; Shonfeld \& Gibson, 2018).

Collaborative learning in online environments is constantly expanding, therefore, a learning theory adapted to the skills required in the information age was 
developed (OCL), sharing skills and knowledge building has been developed based on online collaborative learning (Harasim, 2012). Education systems in different countries combine these skills in teaching and learning, and place a strong emphasis on assimilation (Melamed et al., 2010; Shoenfeld et al., 2010; Mendez \& Rona, 2010). Online collaborative learning is not trivial and does not suit all learners intuitively because collaborative learning in an online environment involves interaction between learners, accessibility and communication that the Web requires. Therefore, it is important to train teachers in the modern era to work collaboratively, and to build a curriculum that includes developing cooperative learning that prepares the students for 21st century reality (Kritz, Bachar, \& Shonfeld, 2018).

\subsection{Autoethnography}

The main studies in the qualitative-ethnographic approach are based on the phenomenological perspective (Karnieli, 2006; Denzin, 2013; Ngunjiri, Chang, \& Hernandez, 2016). This approach is based on a theoretical orientation that focuses on the essence of the experience of the various participants (Moustakas, 1994; Adams, Ellis, \& Jones, 2017). This approach enables starting to research without the need for a clear and defined theory. The theory is constructed as a result of the process of learning and discovery of the subjects being studied, and the manner in which the participants experience the circumstance and interpret it. Hence its name: Grounded Theory (Karnieli, 2006).

This type of research focuses on the way in which the events are perceived and interpreted by the individuals being studied and by the members of the group to which they belong (Holstein \& Gubrium, 1994; Denzin, 2013; Chang, Ngunjiri, \& Hernandez, 2016).

There is no search for one "true" reality, or neutral and objective facts. A base assumption of this approach is that knowledge lies in the meaning people give to their lives and that this affects their behavioral patterns and beliefs. Phenomenological perception is of great importance when the teacher wishes to learn about the processes of instructing, learning and education in educational institutions. This understanding may help to develop curricula and teaching methods adapted to diverse student populations (Karnieli, 2006).

This research-educational approach is especially important in multicultural and heterogeneous societies, such as Israeli society, where the diverse population originates in different cultures, sometimes with a limited common denominator (Karnieli, 2006). Teachers use instruction as a source of research aimed at promoting their professional development (Schon, 1992), using past experience as a basis for future learning through reflective transformation, a state of versatility throughout the process.

Adopting a research-ethnographic approach as a way of life... will help the teacher develop awareness to his students and their needs (Karnieli, 2006; Adams et al., 2017). 


\section{The Research Process}

The autoethnographic research process is based on a faithful description of reality, the naturalistic approach (Karnieli, 2000; Gibbs, 2018; Chang et al., 2016). Research is usually done in place of events.

Practically speaking, the process of inquiry and learning is based on the acquisition of important teacher skills, such as:

Asking questions-improving the ability to identify problems, phenomena or situations in which the information is incomplete. The ability is to present questions relating to an important issue in the field.

Collecting data and information-after formulating the questions or defining the topics that the teacher wishes to research and delve into in order to obtain reliable information, a plan must be devised by which the information will be collected. Its goal is to obtain reliable answers and create a rich knowledge base. At this stage the teacher deals with the issue: what is the relevant material in the professional literature that will enrich their knowledge; how to observe the processes, interactions, and phenomena that they are involved in, and to derive information from them; what to observe in order to gather information and understand processes in the classroom and school. In the case at hand, data collection is done from the blogs written and all the correspondence of the group on the site while performing the requirements of the course.

Extracting Knowledge-after collecting the data on the subject that was studied, and after reading professional literature in the field, the process of extracting knowledge is carried out. In this situation one must identify the questions that emphasize how the social, educational and personal experience is constructed in the examined reality, how and why it bears meaning and what its implications are.

Evaluation and Control-one must keep in mind that due to the researcher's involvement in the creation of the database for which they are the investigating teacher, and have formulated viewpoints and opinions, the process of collecting information and its organization may be biased and even erroneous. Therefore, the investigating teacher must examine their views on the issues they wish to investigate and be aware of the influence of these issues on their attitudes and personal perceptions (Gibbs, 2018).

\section{Findings}

\subsection{Reasons for Choosing the Online Course}

Throughout our academic studies, we can choose some of the courses that we study. The choice of one course or another is not random, yet can a student pause and ask, why was this course chosen?

The blogs that flowed the process of choosing and learning an online course are the pillars this study is based on.

From: Blog No. 1-

"I signed up for an online course with a genuine desire to be exposed to new 
technological tools and to learn to work and study in new areas. Additionally, the desire to experience this type of course which includes group work of an unfamiliar nature."

Choosing to learn a specific course is a routine procedure, perhaps even a technical one. The effort of trying to recall the exact moment I decided on this online course did not help and I found myself unable to recall that moment or thought. I started reading my first blog, I discovered that while was pondering what to write, I had in fact listed the reasons that led me to choose a different sort of course, and the wish to learn and experiment with new and unfamiliar teaching and learning tools.

Blog No. 2-

"Working and learning in a new environment, online and technological environment intrigues me, though is not simple for me, it is a challenge."

After reading the second blog it seems that apparently, under the surface there were other reasons to choose this course. Less formal reasons, along with the obvious rational explanation for this seminar: "Online lessons are a pedagogic tool that I am still learning to use and utilize, and it has great promise and great hope." From the text, curiosity emerges which is reinforced at the end of this blog: "For me, this course is a challenge." However, alongside these feelings, for the first time, the definition of the difficulty arises, which will be discussed at length, later.

Blog No. 3-

"The first online lesson had just ended. I waited and I expected so much, I wanted to be exposed to this new educational tool, but unfortunately, I could not take more of an active role in the lesson since the course includes many participants, all of whom entered the site at the same time, that caused many online communication disturbances. Therefore many students, including me, were constantly being disconnected. My first impression and feelings from that online lesson are obviously complex. I hope to be able to participate in a more active way next time so I could improve my use of this educational tool better next time."

Blog No. 4-

"A new lesson, a new hope, I entered the group task we had during the lesson and here I am 'playing' with a new tool."

\subsection{Interaction between Students}

In traditional courses, the interpersonal encounter takes place in the "conventional" way, where body language and facial expressions are very meaningful, eye contact is formed, and an initial and intuitive communication is formed regarding the students in the course. The creation of study groups is formed through free interactions between the course participants. However, in an online course all these are taken away from the learner and interaction develops in a slightly different way. 
Blog No. 1-

"In this type of course, which contains group work of a new and unfamiliar kind, I could not choose my teammates, I have never met them and yet the cooperation and coordination between us must be complete."

Blog No. 2-

"In order to participate in class while studying a "regular" or "traditionap" course, every college or university student has to get to class, that means to get out of your home or at least from the room at the dormitory. Thus, create a defined time which is learning time, by not being available for geographic reasons. At online learning, the student can participate in class from any possible location. I am at home. In the family living room where the only computer is in the house, but I am not actually at home. I am in class. When studying online, it is a real challenge to make time for learning. The synchronous online lesson requires to make time for it, as I am not away from home, time is an unavailable resource... Time for myself.

In partnership and shared learning "togetherness" is not always active, often the partnership and the "togetherness" seems passive. The active part is each individual learner, in front of the screen, in front of the materials on the site.

Blog No. 4-

"After the class I tried to build a preliminary form as we were asked to, later on I entered the forms presented by the rest of the study group, and discovered that for the first time, I felt the group is working together.

For the first time, the group members contribute to each other, a true collaborative learning was formed. Browsing through their work and the dissections we had on each form, taught me so much... it was a positive experience."

After the first stage of virtual connection between the group students in an online course, the next stage was a face-to-face encounter of all the course students. The blog describes the face-to-face meetings as naturally and ongoing. The regular and "traditional" situation suddenly became more significant and changed the interaction between the members of the group.

Blog No. 6-

"The face-to-face meeting, for me it was the pinnacle of the course. First, meeting the people behind the screen and secondly the amazing communication that was created between us. From the moment we started talking, we did not stop.... until my facilitator kept mentioning that there was a joint task to complete. The tasks in the meeting were meant to connect us, but we did not need them at all. It felt like a returning to a 'normal and natural communications between people, which tied up the bonds that were already formed.

I really enjoyed the meeting. The conversation between all the students, members of the study group and the conversations with the teacher-facilitator of the course. I was a little sorry that the course did not begin with such a meeting... The group's enthusiasm also contributed greatly to the atmosphere, the conversations flowed naturally and openly, there was a great feeling in the air." 
Blog No. 7-

"The Flipped Classroom task. Our group has begun our weekly task, The Flipped Classroom task but the team members are having a hard time. Only half of the group has entered the shared file and contributed.

There is a sense of decline in the group. No one is investing and it's a pity. Maybe they' re investing individually, but not within the group ...It seems that all that we accomplished at the face-to-face meeting is gone..."

Blog No. 8-

“... I have discovered that other study groups are having difficulties as well.

I found myself begging group members to work and collaborate as a study group. In the face-to-face meeting our partnership materialized, but now there is a decline. It seems the study group is falling apart..."

\subsection{Writing a Personal Blog}

The blogs are the source of our findings in autoethnographic research.

The personal blog allows us to study the interactions from the student spear, since the student write it and that place the student at the center (see Figure 1).

Although blogs and posts are a common and accepted form of expression nowadays, writing a blog is not necessarily a daily routine for every student.

Blog No. 1-

"I am writing a blog describing my experience as a student in this online course. I have never written a blog or a post before. I do not really know what to write, but I understand that the blog should reflect how I feel, how do I see this course and it is all about me..."

As shown in Figure 1, the visual metaphoric extends the triangle of levels of engaging into a triangle with a fourth and centered focus. This figure represents the student place in these relations as it takes place when writing a blog. The student becomes the center of focus that all is related to.

\subsection{Coping with an Online Course}

We live in a technological age, an era when computers have long been present in all aspects of our lives, including pedagogy from elementary schools to academic studies, perhaps even mainly in academic studies at colleges and universities.

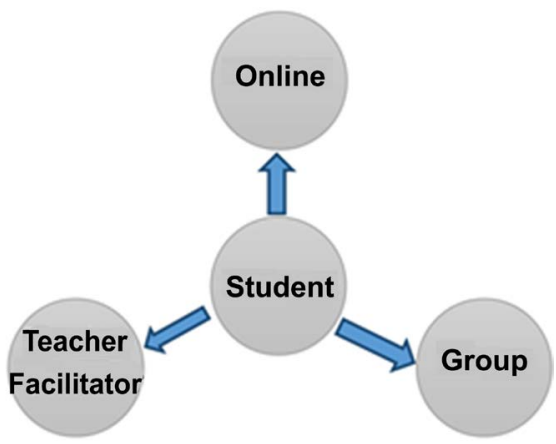

Figure 1. The personal blog places the student at the center. 
Online courses full or partial are available at every teaching college, but what does the learner feel during the online course? What difficulties arise from the blogs that the students experience?

Blog No. 1-

"I am using the online learning platforms, but it is clear to me that I am not making the most out them. Teachers and pedagogic researchers are trying to develop new learning tools in order to improve learning, especially for students who experience difficulties. New applications are constantly coming out in order to make learning easier for those who have difficulties."

Blog No. 2-

"The first online lesson. From my experience with computerized online lessons which disconnected many times during the lesson and there were quite a few difficulties in synchronizing the picture and audio, I entered the site early on the computer and on the mobile phone to see that everything was fine. Unfortunately, everything that worked well before the lesson did not function in real time. I had many difficulties connecting even though I entered the site ahead of time. By the time I was able to reconnect, I had missed some of the instructions and felt like someone who came to the show a quarter of an hour after it began. I was glad that after many attempts and struggles I managed to join, but the sense of joy immediately changed into confusion and loss, "What are they talking about?", "What have they done until now?" "What did I miss?", "How do I catch up as quickly as possible to miss as little as possible?”

The great excitement gave way to disappointment and sadness. The Internet disconnected often. At times the picture got stuck. At times I could not hear the instructor. I am aware that online lessons are a technological tool that I am still learning to use and utilize. I waited so long, I expected so much, I wanted so much for it to go smoothly. I was exposed to new tools, although I could not take more of an active role in the lesson. The course includes many participants, all of whom enter the site at the same time, which is obviously complex.

Blog No. 7-

"When I read the article, I realized that there are people for whom this is an environment which promotes closeness that overcomes obstacles to physical distance and enables communication with people who would never have found an avenue in the real world. Creating a reality that does not really exist and enabling people who could not meet in reality a place to meet. It is clear to me that there are advantages of learning through avatars, though probably not for everyone. I feel alien in this environment."

Blog No. 11-

“... We had finished the Flipped Classroom task. A lot of technological difficulties affected the way we worked.

There were a lot of organizational problems and a lack of familiarity with technological aids in this task."

Blog No. 12-

"International Day... I felt that the lectures from abroad were fascinating, 
though the many difficulties in communication, Internet crashes, voice and image issues have been very difficult."

In dealing with an online course, the student's proficiency in technology is reflected, as well as preliminary assessments of the technological support system, the technical support unit for the course. Unlike in traditional courses, a lack of understanding on the part of the student, or alternatively a discrepancy between the number of users and the preliminary assessments, can derail the studies and the lesson if not the entire course.

As shown in Figure 2, the visual metaphoric extends the triangle of levels of engaging into a triangle with a fourth and centered focus. Any Internet malfunction, problem with bandwidth, "outage", high-speed internet connection or absence of connection can cause an inability to sustain a lesson or activity (see Figure 2).

This figure represents the internet-technical-online place in these relations as it takes place when studding an online course. The online ability become the center of focus that all is related to.

\subsection{Student-Facilitator Interaction}

Designing a course, whether computerized or not, is based on the concept of relations between the lecturer/facilitator of the course and the students.

That relation should not be taken for granted since they influence the student motivation. That relation should be thought of when the course is an online one. Since the very basic interaction, the face to face interaction, that domain the interaction in the" traditional" classroom, does not exist in an online course.

The main audiences at teacher colleges are students, doing undergraduate studies, in their twenties, who were born into a computerized technological world. The Internet as a tool in the service of humankind was in its infancy when they were apparently in their infancy and therefore grew up "with screens". Since the facilitator usually older then the students, the computerized technological world may be challenging. Moreover, the facilitator is no longer "the one that knows it all".

Blog No. 2-

"My feelings towards the upcoming online lesson are very diverse. I feel excited,

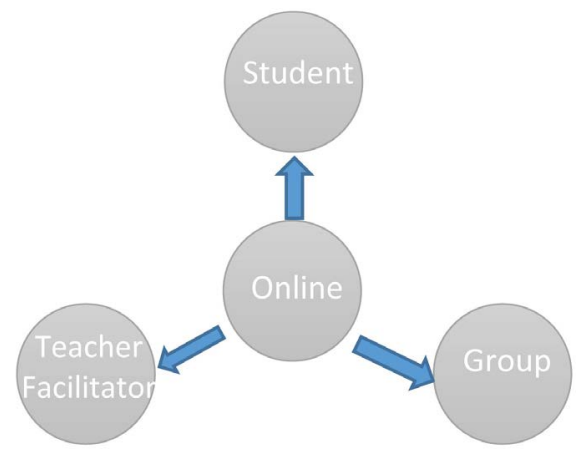

Figure 2. The online-internet-technical placed at the center of an online course. 
and yet there are quite a few fears. Last year I first got to know the computerized Blackboard and now $1 \mathrm{~m}$ learning to use a new tool... The synchronous online lesson requires this unavailable resource. Time. Thus, with online learning I am learning and I am at home. In the family living room, where the only computer in the house is located. I am home and yet, not actually at home. I am in class. I explained to my children the complexity of the situation and prepared them for my being in the living room. The course facilitator has difficulties as well. I do not know if he has any kids, but he is also not fully into the lesson."

Blog No. 5-

"Google tool online lesson. I have discovered a great tool. I saw Google Docs forms in the past sent to my children by their teachers, but I did not know how to create one... I felt I was discovering a great new tool.

It is a great tool for gathering information and data. P $\mathrm{m}$ sure 111 use the tool. Today I could 'feel that my facilitator, knows this tool very well. I could feel his confidence when he talks to us. it reminded me of a traditional class."

Blog No. 6-

"Social media online lesson. I do not have Facebook and I $m$ not a member of any social media network. I understood that this was going to be a problem. $A$ fundamental problem: I understand this is unusual and everyone has Facebook. During the online lesson a balanced assessment of the advantages and risks of the networks were presented but I still choose to stay away. This is going to complicate my task. I asked my facilitator what can I do? I do not seems he knows how to help me, though he really want to."

Blog No. 9-

"A face-to-face meeting, for me, it was the pinnacle of the course. The plenary lecture raised questions and thoughts about our associations and how similar and different they are at the same time because of cultural differences and geographical location. I was amazed that it correlated precisely with what I felt later in the meeting with my group members. Meeting my facilitator face to face for the first time was so exiting. Everything until now seems like, we knew each other but we did not do so much."

Blog No. 10-

"...For me, the virtual world is a new world. When I read the article, I realized that there are people for whom this is an environment which promotes closeness that overcomes obstacles to physical distance... Creating a reality that does not really exist and enabling people who could not meet in reality a place to meet. $I$ feel alien in this environment. $1 \mathrm{~m}$ also uncomfortable, robotic, not human, some of the characters are exaggerated the facilitator created an avatar as well, it felt just as much robotic."

Blog No. 11-

“... I am not a very technological person, but I have discovered that the other group members are also having difficulty. There is a sense of decline. We are having more and more technical difficulties, which the facilitator cannot fix. He is an expert at the subject matter, but online course is so different." 
As shown in Figure 3, the extends the triangle of levels of engaging into a triangle with a fourth and centered focus.

This Figure represents the teacher-facilitator place in these relations as it takes place when in an online course. The ability to communicate though it is not face-to-face as in "traditional" course becomes the center of focus in maintaining connections with the students as a group and as individuals.

\section{Discussion and Conclusions}

The revolution of the 21st century is undoubtedly the revolution of technology, information and social media, its great influence on our lives is evident everywhere we turn, but its impact on education is still developing. Creating information and sharing information on online platforms influences our everyday activities and as a result education and teaching processes. In traditional learning, the inter-personal encounters between the learners and the teacher/lecturer/ facilitator, as well as the interpersonal encounters within the group of learners, creates a dynamic between the lecturer and the learners as individuals and the interaction in a group of learners (see Figure 4).

This dynamic is different in online learning, as emerges from the blogs. It seems that to a certain extent, the triangle that scheme the traditional learning, is lacking the fourth vertex represents the online learning. Therefore, the tetrahedral scheme (see Figure 5) extends the triangle into a third dimension scheme represents all fourth vertex- Student (learner), group, teacher (Facilitator) and online learning.

The blogs reflect that at an online course, the teacher-student-group of students as well as the dynamics among the students themselves showed dependence on the time passed from the beginning of the course.

The initial teacher-student-group affinity created immediately after the introduction stage, at the beginning of the course. As time went by, the interactions decreased, and the group resembled a random collection of individuals rather than a "team". The only observed change in the interactions decrease showed after the "face-to-face" meeting.

It seems that human "traditional" interaction requires body language and eye

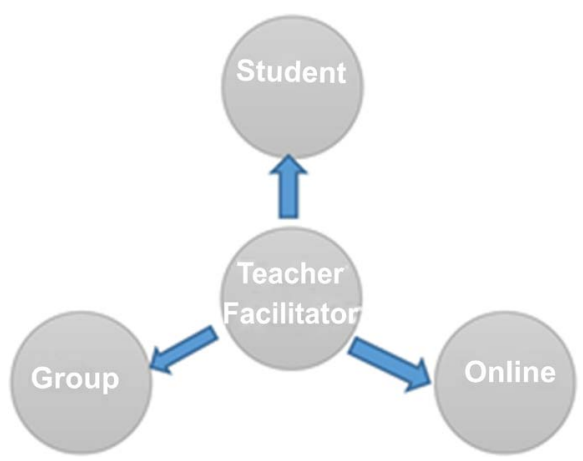

Figure 3. The teacher- facilitator place as the center of connections with the students as a group and as individuals. 


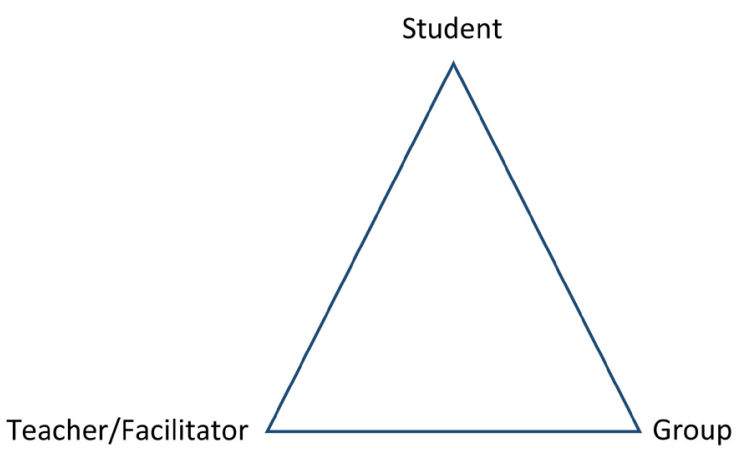

Figure 4. The lecturer (Facilitator)-student (learner)-group dynamic in traditional learning.

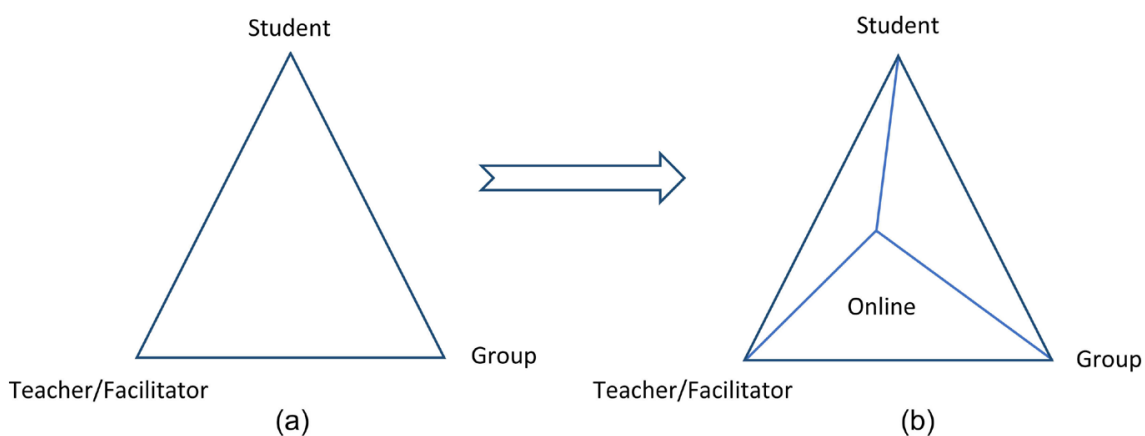

Figure 5. The extension of the triangle scheme to the tetrahedral. (a) The lecturer (Facilitator)-student (learner)-group dynamic in traditional learning; (b) The student (learner)-online-group-teacher (Facilitator) dynamic in online learning.

contact these do not "transfer" through text messages on screens. Therefore, online courses based on online text meetings are lack of these normative human needs that bond people.

In dealing with an online computerized course, not only are the dynamic is different, but also the student's technological abilities. Moreover, a student that was not "born to the age of the Internet and social networks", may interact differently in this type of course for the technical and technological reason. The teacher/facilitator should be aware of that, consciously or sub consciously, and therefore respect to that manner during planing the course structure, the assignments, the contents and the methods of evaluation in the course.

Though according to Karnieli the autoethnographic research process is based on a faithful description of reality, the naturalistic approach (Karnieli, 2000), during which we must examine the events not from "the teacher" point of view who is often personally and emotionally involved in the events and knows them well, rather from "the researcher" point of view (Karnieli, 2006). In order to accurately reflect the Interaction between learners and learner-teacher/facilitator, I had to also look through the lens of "the student", and not just the researcher. That allowed the questioning are we the lecturers fully aware of what is going on in the learning groups in an online course? Can we be fully aware of the interactions in the online course? 
It is now clear to me that this study has changed my automatic reasoning and approach as an educator to online collaborative courses.

\section{Conflicts of Interest}

The authors declare no conflicts of interest regarding the publication of this paper.

\section{References}

Adams, T. E., Ellis, C., \& Jones, S. H. (2017). Autoethnography. In The International Encyclopedia of Communication Research Methods (pp. 1-11). Hoboken, NJ: John Wiley \& Sons. https://doi.org/10.1002/9781118901731.iecrm0011

Beigi, G., \& Liu, H. (2018). Privacy in Social Media: Identification, Mitigation and Applications. ArXiv preprint arXiv: 1808.02191.

Beigi, G., Shu, K., Zhang, Y., \& Liu, H. (2018). Securing Social Media User Data: An Adversarial Approach. In Proceedings of the 29th on Hypertext and Social Media (pp. 165-173). New York: ACM. https://doi.org/10.1145/3209542.3209552

Campbell, J., Hurley, S., Jones, S., \& Stephens, N. (1995). Constructing Educational Courseware Using NCSA Mosaic and the World-Wide Web. Computer Networks and ISDN Systems, 27, 887-896. https://doi.org/10.1016/0169-7552(95)00027-5

Chang, H., Ngunjiri, F., \& Hernandez, K. A. C. (2016). Collaborative Autoethnography. London: Routledge.

Crossman M. D. (1996). The Evolution of the World Wide Web as an Emerging Instructional Technology Tool. In H. B. Khan (Ed.), Web Based Instruction (pp. 19-23). Englewood Cliffs, NJ: Educational Technology Publications.

Denzin, N. K. (2013). Interpretive Autoethnography (vol. 17). Thousand Oaks, CA: Sage Publications.

Dillenbourg, P., \& Schneider, D. (1995). The Mechanisms of Collaborative Learning. Geneva, Switzerland: University of Geneva.

Dillenbourg, P., Baker, M., Blaye, A., \& O'malley, C. (1995). The Evolution of Research on Collaborative Learning. In E. Spada, \& P. Reiman (Eds.), Learning in Humans and Machine: Towards an Interdisciplinary Learning Science (pp. 189-211). Oxford: Elsevier.

Duchastel P., \& Turcotte, S. (1996). Online Learning and Teaching in an Information-Rich Context, Computer Research Institute of Montreal, Canada. http://www.iif.hu/inet_96/c4/c4_1.htm

Gibbs, G. R. (2018). Analyzing Qualitative Data (vol. 6). Thousand Oaks, CA: Sage Publications.

Gillani, B.B., \& Relan, A. (1996). Incorporating Interactivity and Multimedia into Web-Based Instruction. In H. B. Khan (Ed.), Web Based Instruction (pp. 231-237). Englewood Cliffs, NJ: Educational Technology Publications.

Goldberg M., Salari S., \& Swoboda, P. (1996). World Wide Web Course Toll: An Environment for Building WWW-Based Courses. Computer Networks and ISDN Systems, 28, 1219-1231. http://homebrew1.cs.ubc.ca/webct/papers/p29/index.html

Gunawardena, C. N. (1995). Social Presence Theory and Implication for Interaction and Collaborative Learning in Computer Conferences. International Journal of Educational Telecommunications, 1, 147-166.

Harasim, L. (1987). Teaching and Learning on-Line: Issues in Designing Comput- 
er-Mediated Graduate Courses. Canadian Journal of Educational Communications, 16, 117-135. https://doi.org/10.21432/T2TK6K

Harasim, L. (2012). Learning Theory and Online Technologies. New York: Routledge. https://doi.org/10.4324/9780203846933

Harasim, L. (2018). Learning about Learning Online. In B. H. Khan, J. R. Corbeil, \& M. E. Corbeil (Eds.), Responsible Analytics and Data Mining in Education: Global Perspectives on Quality, Support, and Decision Making. Milton Park, Abingdon-on-Thames: Taylor \& Francis Group. https://doi.org/10.4324/9780203728703-9

Harasim, L., Calvert, T., \& Groeneboer, C. (1996). Virtual-U: A Web-Based System to Support Collaborative Learning. In H. B. Khan (Ed.), Web Based Instruction (pp. 149-158). Englewood Cliffs, NJ: Educational Technology Publications.

Harasim, L., Hiltz, S. R., Telese, L., \& Turoff, M. (1995). Learning Networks, a Field Guide to Teaching and Learning Online. Cambridge, MA: The MIT Press.

Hiltz, S. R. (1992). The Virtual Classroom: Learning without Limits via Computer Networks. Norwood, NJ: Ablex Publishing Corporation.

Holstein, J. A., \& Gubrium, J. F. (1994). Phenomenology, Ethnomethodology, and Interpretive Practice. In: N. K. Denzin, \& Y. S. Lincoln (Eds.), Handbook of Qualitative Research (pp. 262-272). Thousand Oaks, CA: Sage Publications.

Hunter, B. (1992). Linking for learning: Computer-and-Communications Network Support for Nationwide Innovations in Education. Journal of Science Education and Technology, 1, 23-24. https://doi.org/10.1007/BF00700241

Islam, N., Beer, M., \& Slack, F. (2015). E-Learning Challenges Faced by Academics in Higher Education. Journal of Education and Training Studies, 3, 102-112. https://doi.org/10.11114/jets.v3i5.947

Jaggars, S., \& Xu, D. (2016). How Do Online Course Design Features Influence Student Performance? Computers \& Education, 95, 270-284.

https://doi.org/10.1016/j.compedu.2016.01.014

Karnieli, M. (2000). Invest in Your Children's Education the Way You Invest in Your Goats: Systemic Educational Intervention in a Traditional Bedouin Community-From Theory into Practice. Educational Action Research, 8, 15-41. https://doi.org/10.1080/09650790000200106

Karnieli, M. (2006). The Diamond Workshop: A Story of Ultra-Orthodox Female Principals. In I. Oplatka, \& R. Hertz-Lazarowitz (Eds.), Women Principals in a Multicultural Society: New Insights into Feminist Educational Leadership (pp. 103-121). Leiden, Netherlands: Sense Publishers.

Konak, A., Kulturel-Konak, S., \& Cheung, G. W. (2018). Teamwork Attitudes, Interest and Self-Efficacy between Online and Face-to-Face Information Technology Students. Team Performance Management: An International Journal. https://doi.org/10.1108/TPM-05-2018-0035

Kritz, M., Bachar, E., \& Shonfeld, M. (2018). An Online Collaborative Learning Model in a Multicultural Environment. In M. Shonfeld, \& D. Gibson (Eds.), Collaborative Learning in a Global World (pp. 111). Charlotte, NC: Information Age Publishing.

Kulik, J. A., Kulik, C. C., \& Cohen, P. A. (1980). Effectiveness of Computer Based College Teaching: A Meta-Analysis of Finding, Review of Educational Research, 50, 525-544. https://doi.org/10.3102/00346543050004525

Magen-Nagar, N., \& Shonfeld, M. (2018). The Impact of an Online Collaborative Learning Program on Students' Attitude towards Technology. Interactive Learning Environments, 26, 621-637. https://doi.org/10.1080/10494820.2017.1376336 
Melamed, U., Peled, R., Mor, N., Shonfeld, M., Harel, S., \& Ben Shimon, I. (2010). Preparing Teachers Colleges to Education in the 21st Century. The Ministry of Education.

Mendez, R. I. C. H. A. R. D., \& Rona, A. L. D. O. (2010). The Relationship between Industrial Placements and Final Degree Results: A Study of Engineering Placement Students. Learning and Teaching in Higher Education, 4, 46-61.

Moustakas, C. (1994). Phenomenological Research Methods. Thousand Oaks, CA: Sage Publications. https://doi.org/10.4135/9781412995658

Ngunjiri, F. W., Chang, H., \& Hernandez, K. A. C. (2016). Using Collaborative Autoethnography to Advance Theory on Women and Leadership. In J. Storberg-Walker, \& P. Haber-Curran (Eds.), Theorizing Women \& Leadership: New Insights \& Contributions from Multiple Perspectives (vol. 103, pp. 87-96). Charlotte, NC: Information Age Publishing.

Othman, A., Ayop, S. K., \& Karim, M. M. A. (2015). The Development and Evaluation of a Blog as the Virtual Interaction Medium for Physics Teachers (38-48). EDUCATUM Journal of Science, Mathematics and Technology (EJSMT), 2, 37-47.

Palloff, R. M., \& Pratt, K. (2002). Lessons from the Cyberspace Classroom: The Realities of Online Teaching. Hoboken, NJ: John Wiley \& Sons.

Petersen, C. (2016). What Does Recent Pedagogical Research Tell Us about eLearning Good Practice? Minnesota eLearning Summit.

Poë, J. C. (2015). Active Learning Pedagogies for the Future of Global Chemistry Education. In J. Garcia-Martınez, \& E. Serrano-Torregrosa (Eds.), Chemistry Education: Best Practices, Opportunities and Trends. Weinheim, Deutschland: Wiley-VCH Verlag GmbH \& Co. KGaA. https://doi.org/10.1002/9783527679300.ch11

Ragoonaden, K. (2000). Collaborative Learning via the Internet. http://ifets.ieee.org/periodical/vol_3_2000/d11.html

Relan, A., \& Gillani, B. B. (1996). Web Based Instruction and the Traditional Classroom: Similarities and Differences. In H. K. Badrul (Ed.), Web Based Instruction (pp. 41-46). Englewood Cliffs, NJ: Educational Technology Publications.

Resta, P., Searson, M., Patru, M., Knezek, G., \&Voogt, J. (2011). Building a Global Community of Policy-Makers, Researchers and Teachers to Move Education Systems into the Digital Age. Edusummit Report, International Summit on Education. Paris: Unesco.

Royer, R. (1997). Learning and Leading with Technology. http://www.amalnet.k12.il/sites/hadshanut/shitotho/had00040.html

Schatz, B. R., \& Hardin J. B. (1994). NCSA Mosaic and the World Wide Web: Global Hypermedia Protocos for the Internet. Science, 265, 895-901.

https://doi.org/10.1126/science.265.5174.895

Schon, D. (1992). Educating the Reflective Practitioner. San-Francisco, CA: Jossey-Bass.

Shneiderman, B., Borkowski, Y., Alavi, M., \& Norman, K. (1998). Emergent Patterns of Teaching/Learning in Electronic Classrooms. Educational Technology Research and Development, 46, 23-42. https://doi.org/10.1007/BF02299671

http://ftp.cs.umd.edu/pub/hcil/Reports-Abstracts-Bibliography/98-04HTML/98-04.ht $\underline{\mathrm{ml}}$

Shonfeld, M., \& Gibson, D. (2018). Introduction to Collaborative Learning in a Global World. In Collaborative Learning in a Global World. Charlotte, NC: Information Age Publishing.

Shonfeld, M., Zelkovitz, Z., \& Goldshtein, O. (2010). ICT Coordinators: The Educators behind the Scenes. In Society for Information Technology \& Teacher Education Inter- 
national Conference (pp. 2386-2389). Association for the Advancement of Computing in Education (AACE).

Somaratne, P. N. (2015). A Review on User Experiences of Collaborative Online Learning. American Scientific Research Journal for Engineering, Technology, and Sciences, 13, 102-109.

Vygotsky, L. S. (1978). Mind in Society: The Development of Higher Psychological Processes. Cambridge, MA: MIT Press.

Vygotsky, L., \& Cole, M. (2018). Lev Vygotsky: Learning and Social Constructivism. Learning Theories for Early Years Practice, 58.

Wigand, R. T. (2018). Virtual Organization and Online Games. In K. Lakkaraju, G. Sukthankar, \& R. T. Wigand (Eds.), Social Interactions in Virtual Worlds: An Interdisciplinary Perspective. Cambridge: Cambridge University Press.

https://doi.org/10.1017/9781316422823.009 